\title{
Non-pharmacological remedies for post-viral acute cough
}

\author{
Giorgio Ciprandi ${ }^{1}$, Maria Angela Tosca ${ }^{2}$ \\ ${ }^{1}$ Allergy Clinic, Casa di Cura Villa Montallegro, Genoa; ${ }^{2}$ Allergy Center, Istituto G. Gaslini, Genoa, Italy
}

\begin{abstract}
The post-viral acute cough (PAC) is a widespread symptom, mainly in childhood and adolescence, and is usually associated with an acute upper respiratory infection, namely the common cold. The use of cough relievers is, therefore, impressive, as documented by the market data. There are many medical devices and dietary supplements for treating PAC, which contain non-pharmacological components. Ancient people used traditional herbs to treat PAC. Thus, a well-established tradition considers natural remedies as an effective and safe way to relieve PAC. The herbal agents include polyphenols, flavonoids, saponins, glucosides, and alkaloids. Also, the European Medicine Agency has recognized the value of plant extracts and other natural substances to treat PAC. Nevertheless, a few studies investigated the role of non-pharmacologic remedies for PAC. There is some evidence for honey, glycerol, Althea officinalis, Drosera rotundifolia, Grindelia, Hedera helix, Pelargonium sidoides, Sambucus nigra, Thymus vulgaris, hyaluronic acid, and saline solutions. However, further rigorous studies should confirm natural products' efficacy and safety to relieve PAC.
\end{abstract}

\section{Introduction}

Acute upper respiratory infections are the most frequent infectious disease and burden the society, from both a social and economic perspective. The common cold, such as acute rhinopharyngitis, is the most prevalent. The common cold symptoms usually

Correspondence: Giorgio Ciprandi, Casa di Cura Villa Montallegro,
Via Monte Zovetto 27, 16145 Genoa, Italy.

E-mail: gio.cip@libero.it

Key words: common cold; post-viral acute cough; non-pharmacological remedy; honey; glycerol; herbal medicines.

Conflict of interest: The authors declare that they have no competing interests, and all authors confirm accuracy.

Received for publication: 25 February 2021.

Accepted for publication: 13 June 2021.

${ }^{\circ}$ Copyright: the Author(s), 2022

Licensee PAGEPress, Italy

Monaldi Archives for Chest Disease 2022; $92: 1821$

doi: 10.4081/monaldi.2021.1821

This article is distributed under the terms of the Creative Commons Attribution Noncommercial License (by-nc 4.0) which permits any noncommercial use, distribution, and reproduction in any medium, provided the original author(s) and source are credited. include cough, sneezing, rhinorrhea, nasal congestion, hypo/anosmia, hypo/ageusia, facial pressure, sore throat, headache, discomfort, myalgias, and low-grade fever [1]. Cough is a symptom mainly due to a protective reflex to clear airways from secretions overload [2]. The definition of acute cough establishes a duration of fewer than four weeks [3]. Acute cough represents the primary reason for accessing primary care doctors [4]. Acute upper respiratory infection, namely the common cold, is the most frequent cause of acute cough in children and adolescents [5]. Viruses, mainly rhinovirus, are the leading cause of common cold; accordingly, the post-viral acute cough (PAC) has come into everyday use [6]. The common cold symptoms usually last less than ten days; acute rhinosinusitis is suspected if they last longer or worsens before [7]. Instead, PAC lasts 3-4 weeks but is generally selfresolving [8]. However, PAC is incredibly annoying for children or adolescents and results in very uncomfortable parents [9].

Consequently, the use of cough-relievers is impressive among people [10]. Alike, doctors frequently prescribe cough-relievers as a first-line treatment for PAC [11]. In this regard, over-the-counter (OTC) products represent a relevant market share. OTC coughrelievers have different action mechanisms, including five drug classes, i.e., antitussive, expectorants, mucolytics, antihistamines, and decongestants [12]. Fixed drug combinations are prevalent and include different molecules, aiming to minimize cough reflex and constitutional symptoms. In this regard, many products contain mainly acetaminophen, ibuprofen, or other non-steroidal antiinflammatory drugs, first-generation antihistamines, mucolytics, and expectorants. However, a recent meta-analysis reviewed the OTC medications for acute cough [13]. The analysis reported that many studies were poorly conducted, with methodological bias, and very different. Thus, there was no good evidence for or against OTC medicines' effectiveness in acute cough. Meanwhile, the regulatory agency withdrew some antitussive drugs because of safety concerns for severe adverse events, including fatalities.

On the other hand, self-care is a growing market worldwide driven by increasing consumer interest in improving their health and well-being. Consequently, there is an increasing interest in non-pharmacological remedies for PAC. Most of them contain natural compounds. It is well known that many people like to customize the therapy choosing "natural" remedies treating PAC, mainly for their children. Consistently, the market data relating to Italy's sales confirm a relevant quote for both dietary supplements and medical devices used to relieve cough and the common cold: the total expenditure is around 200 million per year. Therefore, the current article will present and discuss the most common components in a series of nonpharmacological cough-relievers available in the Italian market as dietary supplements or medical devices (reported in Table 1). It has to be noted that many components belong to traditional western medicine with a consolidated use from a more than millennial tradition for specific substances. In the face of this popular experience, it must be noted that very few substances are supported by scientific evidence provided by randomized controlled trials (RCT). 
Table 1. List of the most common dietary supplements and medical devices marketed in Italy and with the indication for the cough.

\begin{tabular}{|c|c|c|}
\hline Products & Declared active components & $\begin{array}{l}\text { Manufacturing } \\
\text { company }\end{array}$ \\
\hline Algem Manuka Sed & $\begin{array}{l}\text { Manuka honey, Extracts of Alhtea (Althcea officinalis), Thyme (Thymus vulgaris), } \\
\text { Plantain (Plantago major L.), and Grapefruit (Citrus Paradisi Macfad), and Vitamin C (Ascorbic acid). }\end{array}$ & Algem Natura \\
\hline Alteaflu & Honey, propolis, extracts of Althea and Plantain. & Althea Farmacia \\
\hline Aluneb Tuss Junior & Snail extract and hyaluronic acid. & Sakura \\
\hline Arkotos & $\begin{array}{l}\text { Glycerol, honey, Arabinogalactans larch (Larix sp.), thyme leaf extract (Thymus vulgaris L.), } \\
\text { and agave syrup. }\end{array}$ & Arkopharma \\
\hline Balsaben Fitoben & $\begin{array}{l}\text { Hydroalcoholic fluid extracts of mountain pine, tolù balsam, eucalyptus, corn poppy, thyme } \\
\text { (vulgar and wildflower), polygala, and mint. }\end{array}$ & Fitoben \\
\hline Bechiben Fitoben & Hydroalcoholic fluid extracts of corn poppy, licorice, grindelia, elecampane, marshmallow, and mint & Fitoben \\
\hline Bisolmiel & Honey, marshmallow root, and glycerol. & Sanofi \\
\hline Bisolvon Duo Emolliente & Honey, dry extract of Altea root, and glycerol. & Sanofi \\
\hline Broncosulfur & Myrrh, monoterpene, Lavandula Vera and Citrus Reticolata, and N-acetylcysteine. & Laborest Italia \\
\hline Buona Respiro Sciroppo & $\begin{array}{l}\text { Propolis and total polyphenols, Echinacea and echinacoside, zinc gluconate, Rosa canina, } \\
\text { and wildflower honey. }\end{array}$ & Steve Jones \\
\hline Dicotuss & Honey, extracts of ivy and althea. & Labomar \\
\hline Dissolmuco & Honey, thyme extract, ivy dry extract, hyaluronic acid, propolis extract, and Eucalyptus essential oil. & Desa Pharma \\
\hline Droseplus & Tolù balsam, Ipeca, Spongia, Pulsatilla, Coccus cacti, Corallium rubrum, Rumex, Bryonia, and Drosera & Hering \\
\hline Echinacea Tuss & $\begin{array}{l}\text { Echinacea purpurea, altea (Altheae officinalis), linden (Tilia grandfolia), red poppy (Papaver rhoeas), } \\
\text { mullein (Verbascum densiflorum), and helichrysum (Helichrysum italicum). }\end{array}$ & Optima Naturals \\
\hline Eliflu & Alpine snail extract, concentrated raspberry juice, and ascorbic acid. & Princeps \\
\hline Èqui Benetuss & Acacia honey, extracts of plantain and marshmallow. & Èqui \\
\hline Eukin & Wildflower honey, extract of Altheae officinalis and Plantago major. & T2A Pharma \\
\hline Golis Tuss & $\begin{array}{l}\text { Hydroalcoholic extracts of mullein flowers, elecampane root (Inula helenium L.), grindelia } \\
\text { with flowers (Grindelia robusta, Nutt.), and Drosera grass with flowers (Drosera rotundifolia L.), } \\
\text { propolis (Propolis), and essential oils of Eucalyptus (Eucalyptus globulus Labill.) } \\
\text { and thyme (Thymus vulgaris L.). }\end{array}$ & Angelini \\
\hline Grintuss Syrup & $\begin{array}{l}\text { Molecular complex of resins, polysaccharides and flavonoids from grindelia, plantain and helichrysum } \\
\left(\text { Poliresin }{ }^{\circledR}\right) \text {. }\end{array}$ & Aboca \\
\hline Heliluma & Snail extract and concentrated juice of raspberry juice. & CE.M.O.N \\
\hline Helix Med Pediatric & $\begin{array}{l}\text { Wildflower honey, linden flower extract (Tilia platyphyllos or Tilia cordata), snail mucus extract } \\
\text { (Helix aspersa), elderflower dry extract (Sambucus nigra), hydroglycerine extracts of grindelia flower } \\
\text { tops (Grindelia robusta) and plantain leaves (Plantago major), essential oils of eucalyptus leaf } \\
\text { (Eucalyptus globulus) and pine leaf (Pinus sylvestris). }\end{array}$ & $\begin{array}{l}\text { Pharmalife } \\
\text { Research }\end{array}$ \\
\hline Kalumax & Helicis pomatie. & Società Natura \\
\hline Larimucil Bios Line & $\begin{array}{l}\text { Honey, concentrated apple juice, arabinogalactans from larch, extracts of plantain grass with flowers, } \\
\text { Icelandic lichen thallus, and altea root. }\end{array}$ & Bios Line \\
\hline Lichen Sed & Propolis, Cetraria islandica, Uncaria tomentosa, Drosera rotundifolia, and Althaea officinalis. & Promopharma \\
\hline Limax & Snail drool (Elix Aspersa Muller) and concentrated raspberry juice. & Larix Laboratori \\
\hline Lisonatural & Honey, extracts of plantain and thyme. & Sanofi \\
\hline Lumasol & Snail extract, rennet and golden apple juice, and honey. & Fitodorfarma \\
\hline Manuka Benefit Tuss & $\begin{array}{l}\text { Manuka honey, Manuka essential oil, grindelia, Iceland lichen, altea, helichrysum, sundew, primrose, } \\
\text { linden, astragalus and calendula. }\end{array}$ & Optima Naturals \\
\hline Miele di Manuka Kids Syrup & $\begin{array}{l}\text { Manuka honey, Rewarewa honey, essential oils of Manuka, thyme, anise and peppermint, liquorice juice, } \\
\text { and glycerin. }\end{array}$ & $\begin{array}{l}\text { Baule Volante e } \\
\text { Fior Di Loto }\end{array}$ \\
\hline Mucolid & Honey, extracts of altea, drosera, ivy, and snail slime. & Farmaderbe \\
\hline Mucovit Fluxus & $\begin{array}{l}\text { Acacia honey, grindelia flower tops glyceric extract, dry extracts of marshmallow root, fir pine cones, } \\
\text { plantain aerial parts, eucalyptus leaves, Scots pine bark, and common thyme leaves, clear juice of red } \\
\text { currant, and vitamin C. }\end{array}$ & Erba Vita Group \\
\hline Munatoril & $\begin{array}{l}\text { Wildflower and eucalyptus honey, lichen, thyme, ivy, ederacoside, plantain, verbascoside and phenols, } \\
\text { propolis, galangina, and resveratrol. }\end{array}$ & Pharmaluce \\
\hline Pediatuss & Plantago, althea and honey. & Pediatrica Specialist \\
\hline Petit Drill & Glycerol. & $\begin{array}{l}\text { Pierre Fabbre } \\
\text { Pharma }\end{array}$ \\
\hline
\end{tabular}


Antitussive non-pharmacological compounds include different substances, essentially nutrients (honey and its derivatives), vegetalderivative agents (glycerol, hyaluronic acid, balsamic substances), water solutions, and extracts from plants, such as herbal medicines (Table 2).

\section{Honey and its derivatives}

\section{Honey}

Honey is a food produced by bees (Apis mellifera) from nectar or honeydew. Honey is a supersaturated sugar solution [14]. The use of honey in medicine dates back to very ancient times [15]. Already around $4000 \mathrm{BC}$, the Egyptians, and Babylonians used honey to treat respiratory and digestive disorders and soothe the burning of wounds. The ancient Greeks considered honey "the food of the Gods." Coming to the present day, the World Health Organization recommends honey as a cheap, popular, and safe demulcent to relieve PAC in children [16].

Thanks to its viscosity, the saccharides adhere to the irritated mucous membranes creating a protective film that reduces the stimulus of cough and maintains an adequate hydration state, leading to a soothing effect. Honey also has anti-inflammatory, antioxidant, antibacterial, and metabolic activities [17].

RCTs provided evidence that honey is useful for symptomatic

Table 1. Continued from previous page.

\begin{tabular}{|c|c|c|}
\hline Products & Declared active components & $\begin{array}{l}\text { Manufacturing } \\
\text { company }\end{array}$ \\
\hline APropolaid Flu & $\mathrm{N}$-acetylcysteine, propolis, grindelia, drosera, eucalyptus and mint. & Esi \\
\hline Propolac & Propolis, Cetraria islandica, Uncaria tomentosa, Drosera rotundifolia, and Althaea officinalis. & Promopharma \\
\hline S’agapo' & $\begin{array}{l}\text { Wildflower honey, dry lime gold extract (Tilia platyphyllos or Tilia cordata), snail mucus extract } \\
\text { (Helix aspersa), dried elderberry extract (Sambucus nigra), hydroglycerine extracts of grindelia } \\
\text { summit flowering (Grindelia robusta) and plantain leaves (Plantago major), essential oils of } \\
\text { eucalyptus leaf (Eucalyptus globulus) and pine leaf (Pinus sylvestris). }\end{array}$ & S’agapo' \\
\hline Sedatus Plus & Bearberry, elderflower, rosehip, tamarisk buds, and hornbeam. & Named \\
\hline Sedatus Minus & Chamomile, bearberry, linden, and hazel. & Named \\
\hline Sediflu' Tosse Bambini & Eucalyptus honey, extracts of sundew, plantain, ivy, and horehound. & Sakura \\
\hline Sedituss Tosse Secca & $\begin{array}{l}\text { Honey, propolis, hydrolyzed glycosaminoglycans, hydroglycerin extracts of grindelia, mallow, acerola, } \\
\text { plantain, and violet. }\end{array}$ & Desa Pharma \\
\hline Selentuss & Honey, malva, altea and erisimo. & D.M.G. Italia \\
\hline Siromucil & Snail extract and concentrated raspberry juice. & Herbit \\
\hline Stodal & $\begin{array}{l}\text { Bryonia cretica, Cephaelis ipecacuanha, Dactylopius coccus, Drosera Mother Tincture, Euspongia } \\
\text { officinalis, Kalii stibyli tartras, Lobaria pulmonaria, Pulsatilla pratensis, and Rumex crispus }\end{array}$ & Boiron \\
\hline Tossvin & $\begin{array}{l}\text { Acacia's honey, Tolù balsam (Myroxylon balsamum harms) resin fluid extract, hydroalcoholic extracts } \\
\text { of pulmonary (Pulmonaria officinalis l.) aerial parts, poppy (Papaver roheas l.) petals, dry extracts } \\
\text { of plantain (Plantago major l.) leaves, erisimo (Sisymbrium officinale scop.) aerial parts, Icelandic } \\
\text { lichen (Cetraria islandica ach.) thallus; essential oils of eucalyptus (Eucaliptus sp.) and cinnamon } \\
\text { (Cinnamomum zeylanicum l.), and ascorbic acid. }\end{array}$ & Erbenobili \\
\hline Tuikind & Spongia, antimonium sulfuratum aurantiacum, bryonia, sundew, and ipecacuanha. & Loacker Remedia \\
\hline Tusserbe Fluid & Mountain pine, plantain, thyme, and mullein. & Esi \\
\hline Tusserbe Junior & Propolis and Manuka honey, grindelia, pine, plantain, and Icelandic lichen. & Esi \\
\hline Tusserbe Sed & Red poppy, altea, drosera, lichen, and ivy. & Esi \\
\hline Tusseval & Honey, propolis, eucalyptus, grindelia, mallow, and echinacea. & $\begin{array}{l}\text { Marco Viti } \\
\text { Farmaceutici }\end{array}$ \\
\hline Tussiflux & Propolis, mallow, plantain, and Icelandic lichen. & $\begin{array}{l}\text { Pharma Life } \\
\text { Research }\end{array}$ \\
\hline Tussil Sciroppo & $\begin{array}{l}\text { Licorice (Glycyrrhiza glabra L.), grindelia (Grindelia robusta Nutt.), plantain (Plantago lanceolata L.), } \\
\text { ed poppy (Papaver rhoeas L.), sundew (Drosera rotundifolia L.), mullein (Verbascum thapsus L.), } \\
\text { ivy (Ivy helix L .), black currant (Ribes nigrum L.), black alder (Alnus glutinosa Gaertn), hornbeam } \\
\text { (Carpinus betulus L.), acacia honey, vegetable glycerol, star anise (Illicium verum Hook. F.), scots pine } \\
\text { (Pinus sylvestris L.), and grapefruit (Citrus paradisi Macfad.) }\end{array}$ & Bauer Pharma \\
\hline Tussil Baby & $\begin{array}{l}\text { Whole plant sundew, scots pine buds, primrose flowers, rose petals, cornflower flowers, linden flowers, } \\
\text { and purple violet blue petals }\end{array}$ & Bauer Pharma \\
\hline Tussilene & Propolis, extracts of altea, erisimo, horehound, and mallow, essential oils of pine, mint, and eucalyptus. & Erbecedario \\
\hline Tussistin Kind & Drosera and concentrated apple juice & Loacker Remedia \\
\hline Vivin Tosse & Honey, extracts of marshmallow and plantain. & Menarini \\
\hline Weleda Melata di Licheni & Honey, Cetraria islandica (L.), Cladonia rangiferina (L.), Usnea barbata (L.), and Lobaria pulmonaria (L.). & WELEDA \\
\hline Wintuss & $\begin{array}{l}\text { Honey, dry extracts of plantain and Viola tricolor, mallow hydroglycerin extract, mint essential oil, } \\
\text { nd glycerol. }\end{array}$ & PENSA PHARMA \\
\hline
\end{tabular}


relief of nocturnal post-viral cough, reducing cough duration and severity, and improving sleep quality for both children and their parents [18-20]. In particular, honey could be useful in reducing the urge to cough reflex as recently envisaged [21]. A meta-analysis concluded that honey probably relieves acute cough in children to a greater extent than no treatment, diphenhydramine, and placebo, but may make little or no difference compared to dextromethorphan [22].

An RCT provided evidence that honey complexed with resins, polysaccharides, saponins, flavonoids, and sugars, appeared superior to carbocysteine and placebo in the treatment of cough persisting more than seven days [23]. A further RCT showed that this syrup significantly improved nocturnal and daytime cough and sleep quality for both children and parents [24].

Notably, it has to be underlined that honey administration is not recommended in children younger than one year for a high risk of infantile botulism $[25,26]$.

As honey derives from the flowers' nectar, its organoleptic properties depend on the individual flower species' characteristics. Actually, most of the kinds of honey are derived from the collection of multi-floral nectar by bees. However, there are selected productions of honey that derive from the supply of specific monofloral nectar. Consequently, many types of monofloral honey exist, each of which can claim to have different beneficial activities. For example, there is a popular belief that linden and eucalyptus honey are a good cough remedy. In this regard, an RCT evidenced that three types of honey (eucalyptus, citrus, and aromatic herbs) were superior to placebo for nocturnal cough in 300 children with upper respiratory infections [27].

There is also evidence for Manuka honey. Manuka honey derives from the flowers of Leptospermum scoparium, a plant indigenous by New Zealand and Australia. Manuka honey exerts important bactericidal and anti-inflammatory activity, as demonstrated by a randomized controlled trial [28].

\section{Propolis}

Propolis is a resinous mixture that honey bees produce by mixing saliva and beeswax with exudate gathered from tree buds, sap flows, or other botanical sources. It is used as a sealant for unwanted open spaces in the hive. Therefore, propolis exerts bactericidal, and disinfectant activity modulates the immune response and is

Table 2. Main non-pharmacological classes of components used for relieving the post-viral cough and other symptoms of the common cold.

\section{Natural products}

Honey (including Manuka honey) as a food

Honey blended with complex extracts of herbal medicines

Propolis

Complex extracts of herbal medicines (usually as a blend)

Glycerol (alone or as syrup ingredient)

Oral herbal medicines (usually as blend)

Nature-derived isolated compounds (glycerol, eucalyptol, menthol, thymol)

Resveratrol

Lactoferrin

Nasal sprays with herbal medicines

Vitamins and oligoelements

Nasal irrigation with saline, thermal water, or hyaluronic acid commonly used in upper respiratory infections [29]. Propolis may be adequately extracted and fractioned to select the active components, such as pinocembrin, galangine, and acid caffeic ester. There is evidence that propolis components are useful in treating patients with PAC [30-33].

\section{Vegetal-derivative agents}

\section{Glycerol}

Glycerol is a colorless, odorless, and viscous liquid; it is found naturally in all cells in the form of triglycerides, and it occurs naturally in most products of fermentation [34]. Due to its lubricating and demulcent activity and sweetness, glycerol could contribute up to $85 \%$ of cough syrups' benefit $[35,36]$. The humectant properties of glycerol are due to three hydrophilic alcoholic hydroxyl groups in its chemical structure that can attract and bind to molecules of water and, additionally, to exert a plasticizing effect preventing drying out mucosal dryness. Notably, glycerol administration has not been associated with adverse effects, except in very high concentrations when a dehydrating effect is apparent [37]. Interestingly, the World Health Organization and British Medicines and British Healthcare Products Regulatory Agency promoted the use of cough-reliever syrups containing glycerol [38,39]. It is plausible that the glycerol effectiveness in improving acute cough depends on mechanisms similar to honey. Both compounds exert a relevant demulcent activity.

Notably, glycerol can be used as early as six months of age.

\section{Menthol}

Menthol is cyclic monoterpene alcohol with balsamic, analgesic, antifungal, antipruritic, anti-inflammatory, antitussive, antiviral, insecticidal activities exert antitussive effects as is an agonist of the Transient Receptor Potential (TLR) receptors M8 [40]. The freshness sensation is perceived immediately after being placed in the mouth. Menthol is, therefore, commonly present in many cough-reliever products [41-43]. However, it may be toxic at high concentrations [44].

\section{Eucalyptol}

Eucalyptol is a cyclic ether and monoterpenoid. It has balsamic, anti-inflammatory, and antioxidant activity [45]. It is popularly used to relieve cough. It acts on TLR receptors [46]. As though menthol, eucalyptol is widely used in many cough-reliever natural products.

\section{Thymol}

Thymol is the main monoterpene phenol occurring in essential oils isolated from plants belonging to the Lamiaceae family, mainly in Thymus vulgaris [47]. Thymol is employed for positive balsamic, antioxidant, anti-inflammatory, local anesthetic, and antiseptic activity to relieve cough [48].

\section{Myrrh}

Myrrh is a natural resin derived from the Commiphora plant. It is rich in tannins, resins, polysaccharides, and flavonoids; thus, it is used in medicine because of analgesic activity and antitussive activity in children [49]. Its chemical property (resin) is also used to bind plant extracts in some complex natural products. 


\section{Resveratrol}

Resveratrol is a non-flavonoid phenol and a phytoalexin naturally produced by numerous plants in response to attacks by pathogens such as bacteria or fungus [50]. It has anti-inflammatory, antioxidant, and antiviral activity. Two studies demonstrated that resveratrol effectively relieved cough in children with the common cold [51] and recurrent respiratory infections [52].

\section{Hyaluronic acid}

Hyaluronic acid (HA) is a main component of the extracellular matrix and has a crucial role in tissue regeneration and inflammation response [53]. HA is a regular constituent of airway secretions. Indeed, HA is present at the ciliary border of the lining epithelium respiratory mucosa and secretions of the airways; here, HA maintains the airways' physiology, thanks to its peculiar characteristics chemical-physical. The viscoelastic properties of HA and its ability to hydration and lubrication depend on the high molecular weight. Furthermore, being HA, a highly hygroscopic molecule, plays an essential role in modulating surface osmotic balance [54].

In summary, the main actions of HA, especially of high molecular weight, can be identified in: i) hydration (HA thanks to its hygroscopic properties and lubricants, helps keep the hydrated nasal mucosa, a necessary condition for humidifying and purifying the inhaled air; ii) repair (HA has an emollient action and soothing that relieves symptoms caused by irritation or inflammation while promoting processes repair of the respiratory mucosa); iii) protection (HA contributes to maintaining a significant protective barrier against agents external harmful and pathogens), and iv) immunological (HA interact with the CD44 receptor involved in the mechanisms of adhesion and migration of immunocompetent and inflammatory cells and modulates the activity kallikrein-1).

It is commonly used in many products for nebulization or nasal spray. Two studies showed that inhaled hyaluronic acid significantly improved respiratory symptoms, including cough, in children with an acute respiratory infection $[55,56]$.

Table 3. Principal single natural components contained in the dietary supplements and medical devices for the cough. Components with evidence by RCT are in bold.

\begin{tabular}{ll}
\hline Agave americana & Malva sylvestris \\
Aloe vera & Mentha piperita \\
\hline Althea officinalis & Myroxylon balsamum \\
Cetraria islandica & Papaver rhoeas \\
\hline Citrus paradisi & Pelargonium sidoides \\
Citrus reticulata & Pinus mugo \\
\hline Drosera rotundifolia & Plantago major \\
Echinacea purpurea & Polygala \\
\hline Eucaliptus globulus & Populus nigra \\
Glycyrrhiza glabra & Ribes nigrum \\
\hline Grindelia robusta & Rosa canina \\
Hamamelis virginiana & Salvia officinalis \\
\hline Hedera helix & Sambucus nigra \\
Helichrysum italicum & Thymus vulgaris \\
\hline Helix pomatia & Tilia platyphillos \\
Helix aspersa & Uncaria tomentosa \\
\hline
\end{tabular}

\section{Water solutions}

\section{Saline solution}

Upper airways should be clean and open to regular function [57]. Hypersecretion of mucus causes posterior rhinorrhea that in turn causes the post-nasal drip. Secretion dripping triggers irritant receptors and, as a consequence, elicit cough reflex. Saline irrigation or nasal spray, using the isotonic or hypertonic formulation, is commonly used in children with upper respiratory infections [5861]. Also, thermal water is useful in treating upper airway diseases, relieving cough [62]. Notably, salsobromoiodine thermal water may be added with natural substances and hyaluronic acid to improve its efficacy, as recently demonstrated $[63,64]$.

Moreover, the saline solution may be frequently combined with active components, such as hyaluronic acid and/or plant extracts, with synergic effects. Noteworthy, as PAC depends on the accumulation of secretions, their removal could represent a necessary treatment in infants less than six months of age. Nasal washing and humidification are the only safe, effective procedures adopted in infants with PAC.

\section{Plant extracts}

Traditional western medicine is a popular remedy to treat common cold symptoms and, in particular, cough. Many plant extracts are used, even though the rationale is frequently based on the empirical ground. However, some recent studies provided evidence that some components are effective in relieving post-viral acute cough. In this regard, the European Medicine Agency recognized the validity of some natural compounds and started a regulatory function to define recommendations collected in a monograph [65]. EMA selected some plants effective in cough relief. Here, we present, in alphabetic order, some plant extracts whose clinical efficacy has been documented. These components are common ingredients of products available as a medical device or dietary supplement, as reported in Table 1 and 3.

\section{Adhatoda vasica (Justicia adhatoda)}

Adatoda is a medicinal plant of the Acanthaceae family, a native of Asia. The active ingredients are alkaloids (vasicine, vasicin $\mathrm{N}$-oxide, vasicinone, deoxivasicin, mayiontone), essential oil, and adatodic acid [66]. Adatoda has bronchodilator, antihistaminic, expectorant, mucolytic, and antiseptic activities. The primary active alkaloid, vasicine, and its self-oxidation product, vasicinone, produce prolonged bronchodilation comparable to that obtained with theophylline, due in part to depression of the vagal nerve endings at the bronchial level, in part to a true antihistamine stabilizing action, decreasing the resistance to respiratory flow [67]. The essential oil with the alkaloid principles acts by depolymerizing the mucoproteins (the mucus dissolves becoming less dense) and stimulating the respiratory system (thus favoring the mucus' clearance itself).

Adatoda is indicated to relieve cough [68]. An RCT showed a fixed combination of aqueous ethanolic extracts of Justicia adhatoda leaf, Echinacea purpurea root, and Eleutherococcus senticosus root exerted significant antitussive effects in patients with an upper respiratory infection [69]. 


\section{Agave americana}

Agave is a succulent plant typical of tropical countries and belongs to the Agavaceae family. Agave contains volatile oil, agave gum, phloionolic acid, oxalic acid, oxalates of various kinds, a saponin (echogenin), sugars (in particular agavose), pectins, and resins. Agave is a healing plant, used for a long time as a remedy in folk medicine; fresh and dried leaves exert an anti-inflammatory action and calm irritations. A study compared agave nectar, placebo, and no treatment in infants and toddlers with acute cough. Interestingly, the placebo effect was significantly superior to no cure, and there was no additional benefit offered by agave nectar [70]. This outcome is very relevant as underline the placebo's therapeutic value and highlights the need to perform RCT with a placebo arm.

\section{Aloe vera}

Aloe belongs to the Aloaceae family. The use of aloe is very ancient, as evidenced by the cuneiform text of some clay tablets found in the Mesopotamian city of Nippur, near Baghdad, Iraq, and datable to around $2000 \mathrm{BC}$. In a tablet, it was written: the leaves looked like sheaths of knives. Aloe was also known and used by the Egyptians (as mentioned in the "Ebers papyrus" of $1550 \mathrm{BC}$ ). There is a popular thought that aloe has many beneficial properties. Agave regenerates the damaged mucosa and exerts anti-inflammatory, moisturizing, hydrating, analgesics, fungicide, antiviral, antibacterial, hemostatic, and lenitive: relieves itching [71]. However, no study investigated its efficacy in subjects with PAC.

\section{Althea officinalis}

Marshmallow belongs to the Malvaceae family. The juice is the main ingredient and is extracted from the root. The high content of mucilage explains the emollient, laxative, and calming properties. Althaea officinalis is used for the treatment of cough for centuries. The topical application of marshmallow roots' medicinal extracts shows immediate effects like a protective film on the inflamed mucosa. The soft layer reduces the mucosa's irritation and protects the respiratory tract from environmental injury, including viral infections. An in vitro study demonstrated antiinflammatory and antioxidant activity on macrophages [72]. Moreover, marshmallow has expectorant and antitussive effects. A recent review stated that the results of animal and clinical studies confirmed the efficacy of $A$. officinalis, combined with other plant extracts, in the treatment of cough [73].

\section{Cetraria islandica}

Icelandic lichen is a species of fruticose terricolous lichen typical of the lava fields in Iceland. The thallus contains: polysaccharides (lichein and isolichein), bitter lichenic acids (usnic and cetraric acid), folic acid, and other vitamins of group B. Usnic acid gives the plant an antimicrobial and antiseptic activity useful in the presence of respiratory diseases. Lichenin produces mucilage, a jelly, with marked mucolytic, decongestant, and expectorant action [74]. However, no study investigated its efficacy in subjects with PAC.

\section{Citrus paradisi}

Grapefruit is a fruit tree belonging to the genus Citrus and the citris family. Some studies highlight the broad-spectrum antifungal, antimicrobial and antibacterial properties of grapefruit seed extract [75]. It has been reported that the seeds fight more than 800 different types of bacteria and viruses [76]. Besides, it contains hesperidin, a flavonoid with antioxidant, anti-inflammatory, and immunomodulating properties [77]. Therefore, grapefruit seeds are thought to be useful for treating common cold symptoms, including cough. Two studies confirmed this activity $[63,64]$.

\section{Citrus reticulata}

Mandarin is a fruit tree belonging to the genus Citrus. The peel of the mandarin contains limonene, an antioxidant substance [78]. In Traditional Chinese Medicine, mandarin is included in the classification of therapeutic foods, namely, the infusion with mandarin zest is indicated for cough. However, no study investigated its efficacy in subjects with PAC.

\section{Drosera rotundifolia}

Sundew is a carnivorous plant of the Droseraceae family. It contains significant amounts of polysaccharides and polyphenols, mainly quercetin and isoquercetin $[79,80]$. The leaves of sundew are used to relieve cough thanks to the flavonoids and derivatives of ellagic acid [81]. Also, the extracts of the aerial parts have antimicrobial activities. Drosera produces various secondary metabolites, including naphthoquinones, which displays antiinflammatory and antimicrobial properties [82]. A homeopathic drug-containing also extracts sundew was superior to placebo in relieving acute dry cough in children [83].

\section{Echinacea purpurea}

This plant's medicinal use is lost in time: the Amerindians of North America used the rhizome to treat wounds and various skin diseases, wounds from trauma, from snake bites, smallpox, measles, epidemic mumps, arthritis, and preparation of mouthwashes.

The modern pharmacopeia has extended popular knowledge by attributing a role in strengthening the immune defenses. Echinacea can also be used for the treatment of the common cold. The European Medicines Agency (EMEA) has approved Echinacea purpurea flower extract for the short-term prevention and treatment of common cold [65]. The agency recommends that it should not be taken for more than ten days. Administration to children under the age of 1 year is contraindicated due to possible side effects on an immature immune system.

Moreover, children between 1 and 12 years of age are not recommended, as the efficacy has not been sufficiently documented [84]. In the absence of sufficient data, use during pregnancy and lactation is not recommended. The British Medicines and Healthcare products Regulatory Agency has expressly advised against Echinacea's administration to all children under the age of 12 due to the risk of developing severe allergic reactions; risk which, although not frequent, remains higher than that of any expected benefits.

A meta-analysis concluded that the use of different Echinacea preparations prevents subsequent upper respiratory infections in children [85]. However, a more recent Cochrane meta-analysis concluded that Echinacea products had not been shown to provide benefits for treating the common cold symptoms, although there may be a weak benefit from some Echinacea products [86]. The results of individual prophylaxis trials consistently show positive (if non-significant) trends, although potential effects are of questionable clinical relevance [85]. A systematic review and metaanalysis evaluated Echinacea's role in treating cough and revealed limited evidence for this plant [88].

\section{Eucalyptus globulus}

Eucalyptus is an evergreen tree of the Myrtaceae family. The essential oil is extracted by steam distillation of the fresh leaf. It is composed of about $70 \%$ cineole. It is used in many multi-compo- 
nent products for relieving cough. A multi-component product containing camphor, menthol, and eucalyptus oils in a petrolatum base, was superior to petrolatum alone or no treatment in reducing cough in children [87].

\section{Glycyrrhiza glabra}

Licorice is a perennial herbaceous plant belonging to the Fabaceae family. The most important active ingredient in licorice is glycyrrhizin, which plays anti-inflammatory and antiviral action. Glycyrrhizin exerts anti-inflammatory activity by modulating the production of inflammatory cytokines, inhibiting reactive oxygen species accumulation, reducing inflammatory exudates, and increasing the production of endogenous interferon [88]. Moreover, glycyrrhizin binds to a pocket of HMGB1 protein, preventing the link with its receptor. HMGB1 protein is a nuclear protein belonging to the group of damage-associated molecular patterns. These proteins are released into extracellular liquid after cell damage, and they amplify the message of damage occurred, inducing the activation of the immune cells [89]. In this context, glycyrrhizin's topical use significantly reduced two important proinflammatory cytokines, TNF-a and IL-1b [90].

Moreover, the complex glycyrrhizin-HMGB1 effectively reduces the inflammatory infiltrate [91]. Glycyrrhizin also has antiviral activity [92]. Licorice contains a potent antitussive compound (liquilitin apioside) whose antitussive effect may depend on peripheral and central mechanisms [93]. An RCT showed that glycyrrhizin therapy was associated with shorter hospitalization, lower-grade fever, and lower treatment cost than placebo in patients with viral upper respiratory infections [94].

\section{Grindelia robusta}

Grindelia robusta is a medicinal herb of the sunflower family that is composed of different diterpenoid natural products. Its major constituents are grindelic acid and related grindelane diterpenoids [95]. It exerts expectorant, antitussive, and anti-inflammatory activity. Traditionally, it was used by Californian indigenous populations to relieve cough.

In a commercial product, Grindelia is combined with other plant extracts, including Helichrysum and Plantago, and honey. Two RCTs provided positive outcomes in children with post-viral acute cough $[27,28]$.

\section{Hamamelis virginiana}

Hamamelis virginiana belongs to the Hamamelidaceae family. It contains abundant tannins, triterpenes, and flavonoids. It has antiviral, antioxidant, and anti-inflammatory activity [96-98]. A natural product contains extracts from Hamamelis and Thymus, particularly abundant of tannins and flavonoids. These components are associated with rock salt. However, no study investigated its efficacy in subjects with PAC.

\section{Hedera helix}

Common ivy is a plant belonging to the Araliaceae family. The main components of ivy are saponins, a group of active ingredients that lowers mucus' surface tension, making it thin. The ivy also contains essential oils, which have a bactericidal action, and tannins, with astringent activity. Some studies explored its coughrelieving activity.

A study showed that an herbal medicine containing ivy leaf dry extract administered twice a day in 5162 children with productive cough significantly reduced cough [99]. A prospective, open, noninterventional study was conducted at 25 medical practices throughout Switzerland to compare a syrup containing ivy leaf extract acetylcysteine with acetylcysteine in children and adults with cough [100]. The ivy leaf extract was significantly better than acetylcysteine in reducing cough attacks and improving coughassociated sleeping disorders. A placebo-controlled RCT showed that granules containing ivy extract significantly improved cough and common cold symptoms in children [101].

An open study evaluated a combined herbal preparation containing ivy and thyme extracts in patients with acute respiratory infection [102]. This compound reduced cough and expectoration.

\section{Helichrysum italicum}

Helichrysum italicum belongs to the Asteraceae family. Helichrysum's main action is antioxidant, thanks to the high content of polyphenols, flavonoids, and coumarins. These substances protect against the ROS free radicals [103]. Helichrysum italicum acetophenones, flavonoids, and phloroglucinols demonstrated inhibitory action in different arachidonic acid metabolism pathways and other pro-inflammatory mediators [104]. Therefore, it is used to treat cough in traditional medicine [105].

\section{Helix pomatia and Helix aspersa}

Snail syrup can be formulated with extracts of Helix pomatia (also known as a Burgundian snail or vine grower) or with extracts of Helix aspersa (or knurled snail), both gastropod mollusks belonging to the Helicidae family [106]. The extracts of these snails contain mucopolysaccharides with fluidifying and expectorant properties [107]. These extracts are included in some multicomponent syrups for cough. However, no study investigated its efficacy in subjects with PAC.

\section{Malva sylvestris}

Wild mallow is a plant belonging to the Malvaceae family. The name derives from the Latin mallow and has the meaning of springs because its emollient properties have been recognized since ancient times. In particular, the flowers and the leaves of the mallow are rich in mucilage, terpenoids, and phenols, with emollient and anti-inflammatory properties [108]. These active ingredients work by coating the mucous membranes with a viscous layer that protects them from irritants. For this reason, the use of mallow is indicated against cough and the common cold. However, no study investigated its efficacy in subjects with PAC.

\section{Marrubium vulgare}

The horehound is a small herbaceous perennial plant with labiati flowers belonging to the Lamiaceae family. The plant contains essential oil, triterpenes, flavonoids, polyphenols, bitter substances, tannins, sesquiterpene lactones, and mucilage [109]. Horehound is used as a mucolytic and cough suppressant [110]. The primary mechanism is linked to forming a protective film on the mucous membranes, thanks to mucilage [111].

\section{Mentha piperita}

Peppermint is a perennial herbaceous plant, stoloniferous, intensely aromatic, which belongs to the Labiate family (Lamiaceae) and the genus Mentha. The main components of mint are an essential oil rich in menthol and menton, enzymes (oxidase and peroxidase), $\mathrm{C}$ vitamin, phenolic acid, caffainic acid, flavonoids, and tannins [112]. Traditional medicine recognizes expectorant, balsamic, analgesic, and antiseptic (antibacterial and antiviral) activities. A randomized study compared a spray containing aromatic essential oils of five plants (Eucalyptus citriodora, Eucalyptus glob- 
ulus, Mentha piperita, Origanum syriacum, and Rosmarinus officinalis) as applied five times a day for three days with a placebo spray in patients with upper respiratory infections [113]. The product was significantly effective in relieving symptoms 20 minutes after administration, but not after three days of treatment.

\section{Myroxylon balsamum}

Myroxylon balsamum is a tree of the Fabaceae (or Leguminosae) family, widespread in tropical areas and Polynesia. The balsam of Tolù is obtained from this plant, from the Colombian town of Tolù. About $80 \%$ of the oleoresin contains benzoic and cinnamic esters of tolu resin-tannol. The drug has a fair amount of free benzoic and cinnamic acid. There are also esters, such as benzyl benzoate and cinnamate, a small amount of vanillin. Eugenol, ferulic acid, and triterpenoids increase the fluidity of secretions, exerting a balsamic effect. It supports eutrophism of the mucous membranes [114]. However, no study investigated its efficacy in subjects with PAC.

\section{Papaver rhoeas}

The common poppy is an annual herbaceous plant belonging to the Papaveraceae family and is one of the oldest remedies in popular herbal medicine. It has always been used for its sedative properties of coughs, which calm spasms, favor expectoration, and facilitate sleep. In the petals were found low quantities of alkaloids: isoquinolic alkaloids $(0.7 \%)$ of which roeadin (tetrahydrobenzazepine) is the majority [115]. This alkaloid was found in all parts of the plant except the seeds. There are other alkaloids in the aerial parts, such as protopin (also in the roots), captisin, sanguinarine, cheleritrina, anthocyanin glycosides (mecocyanine, cyanine, and others), and mucilage. The seeds contain fatty oil (35\%), mainly linoleic, oleic, palmitic, and stearic acids. Popular medicine attributes to Roeadin sedative and cough-relieving properties useful to treat common cold [116].

\section{Pelargonium sidoides}

Pelargonium belongs to the Geraniaceae family. The extract of the roots of this geranium contains secondary compounds, including coumarin derivatives (umckalin), gallic acid and its esters, flavonoids (quercetin), flavan-3-oils (catechins), and phytosterols. Pelargonium extract reduces the use of antibiotics for acute respiratory infections [117]. Moreover, Pelargonium has antiviral and antibacterial effects, modulates the release of TNF- $\alpha$ and nitric oxides, stimulates interferon- $\beta$, and increases natural killer cell activity [118]. A meta-analysis found 11 RCTs exploring the Pelargonium activity in patients with post-viral cough [119]. The level of evidence was considered moderate $(\mathrm{RR}=4.6)$.

\section{Pinus mugo}

The mountain pine, or simply mugo, is an evergreen needlelike bush, with a prostrate habit, belonging to the Pinaceae family. The essential oil contains terpene compounds and esters (for 4$10 \%$ ), especially bornyl acetate; the leaves contain esters, resins, and glycosides [120]. The essential oil has antiseptic and mucolytic properties; it can also be used to carry out fumigations with hot water in cough, cold, and phlegm [121].

\section{Plantago major}

Plantain belongs to the Plantaginaceae family. It contains polysaccharides and polyphenols with antibiotic activity [122]. Plantain leaves contain iridoid glycosides, flavonoids (luteolin), mucilage, tannins, pectins, and salic acid. These active components give plantain antitussive, expectorant, antibacterial, antiinflammatory, and astringent properties. The anti-inflammatory action of plantain is due to the aucubin, in which hydrolysis releases a bicyclic genin, called aucubigenin [123]. This active ingredient has a marked antiallergic and decongestant property, whose mechanism of action is expressed in inhibiting the synthesis of pro-inflammatory mediators [124]. Plantain is traditionally used in traditional Persian medicine to relieve cough [125].

\section{Polygala}

Polygala is a genus of spermatophyte Dicotyledonous, arboreal, herbaceous, climbing, and perennial plants, belonging to the Polygalaceae family. The etymological origin of the name of the plant dates back to an ancient belief. It was thought that this botanical species was able to stimulate the production of milk in cows. Polygala, in Greek, really means 'much milk.' This belief was then extended to pregnant women, thinking that it could stimulate milk's secretion in abundance. The polygala contains saponins, triterpenes (senegine), flavonoids, salicylic acid, tannins, and resin [126]. The polygala has mucolytic and expectorant activity, conferred mainly by the saponins. Native Americans use this plant as an anti-inflammatory remedy for the treatment of common colds [127].

\section{Populus nigra}

The black poplar is a tree species of the genus Populus. The constituents of the poplar tree are glycosidic derivatives (salicin, salicortin), benzene derivatives (tremuloidin, populin), tannins, trisaccharides, triterpenes, and resins [128]. Anti-inflammatory, antioxidant, balsamic, and expectorant activities, counteract cough, and phlegm [129].

\section{Ribes nigrum}

Blackcurrant (is a plant belonging to the Grossulariaceae family. The buds are rich in essential oil, flavonoids, and glycosides. Blackcurrant has a cortisone-like activity by increasing the production of adrenal steroids [130]. Therefore, the blackcurrant bud extract is used for its natural anti-inflammatory and antihistaminic property that acts on the respiratory tract. The pulp is rich in anthocyanosides, belonging to the flavonoid family, mirtillin, tulipanin, chrysanthemum, and antirrinin [131]. The traditional medicine recommends blackcurrant for the common cold and cough [132].

\section{Rosa canina}

Sweetbriar is a plant belonging to the Rosaceae family. It is the most common spontaneous rose species in Italy, very frequent in hedges and on the edges of woods. Sweetbriar contains L-ascorbic acid, pectins, tannins, essential oil, carotenoids, anthocyanosides, and flavonoids [133].

Rosa canina extracts are used as antioxidants, immunomodulators, vitamins, antiasthenics, and adjuvants in flu syndromes [134]. The extracts are recommended for cough and the common cold.

\section{Salvia officinalis}

Common sage is a small herbaceous perennial plant with delicate labiati flowers belonging to the Lamiaceae family. The plant contains flavonoids, essential oil (ketones, borneol acetate, pinene, and camphor), derivatives of caffeic acid (chlorogenic and rosmarinic acid), diterpenes and triterpenes, and tannins [135]. Sage is a plant with some therapeutic properties, such as antibacterial, antifungal, antiviral, and astringent [136]. Traditional medicine uses sage for common cold and cough [137]. 


\section{Sambucus nigra}

The elder is a dicotyledonous angiosperm plant belonging to the Adoxaceae family and the genus Sambucus. The elder has medicinal-herbal properties in fruits and flowers. All the rest of the plant (including seeds) is poisonous since it contains the glycoside sambunigrin. The flowers contain tannins, unrutoside, and the glucoside sambunigroside; the fruits contain tannins, pectins, traces of essential oil, organic acids, and mineral trace elements $[138,139]$. Elderberry has been used in folk medicine for centuries to treat influenza, common cold, and sinusitis and has been reported to have antiviral activity against influenza and herpes simplex [140].

An RCT investigated the efficacy and safety of oral elderberry syrup for treating influenza A and B infections [141]. Symptoms were relieved, on average, four days earlier, and the use of rescue medication was significantly less in those receiving elderberry extract than placebo. Another RCT significantly reduced the common cold duration and severity in air travelers [142]. A recent review suggested that $S$. nigra berry (in extract or lozenge formulation) may reduce influenza-type symptoms, including fever, headache, nasal congestion, and rhinorrhea, when taken within the first 48 hours of symptom onset [143]. Within 2-4 days of $S$. nigra treatment, most patients experienced significant symptom reduction by an average of 50\%. Evidence regarding the effectiveness of $S$. nigra berry on the symptom of cough and the need for/use of medicines (including antibiotics) to treat acute respiratory infections is currently unclear and inconsistent. A meta-analysis reported that supplementation with elderberry was found to reduce upper respiratory symptoms substantially [144]. The meta-analysis suggested that the reported outcomes might be an alternative to antibiotic misuse for upper respiratory symptoms due to viral infections and a potentially safer alternative to prescription drugs for routine cases of the common cold and influenza [145].

\section{Thymus vulgaris}

Thyme is a genus of plants of the Lamiaceae family. Thyme contains flavonoids and essential oils, including thymol, carvacrol, borneol, linalol, and pinene. Its extracts are traditionally used to relieve cough. It has anti-inflammatory, antiseptic, antibacterial, antioxidant, antimicrobial, and immune-stimulating activity $[146,147]$. Thyme extracts combined with other herbal plants have been tested to show significant relieving cough [148-150].

\section{Tilia platyphyllos}

The linden is a genus of arboreal or shrubby plants of the Tiliaceae family.

Flowers with bracts contain flavonoids, including glycosides of quercetin and kaempferol, tannins, mucilage, aromatic (caffeic, chlorogenic, gallic) and organic acids (malic, tartaric, acetic), and essential oil; the sapwood contains: phenolic acids, tannins; and the gems contain auxins, gibberellins, and growth factors [151]. Linden extracts have anti-flu, antipyretic, sedative, expectorant, and mucolytic properties [152].

\section{Uncaria tomentosa}

Uncaria is an original plant of the Peruvian jungle and a liana of the Rubiaceae family, named for the thorns that resemble cats' nails. The root and bark of this plant contain phenolic alkaloids, healing agents, antacids, oxindol alkaloids, glycosides of quinovic acid, polyhydroxylated triterpenes [153]. The Uncaria has immune-stimulating, antiviral, anti-inflammatory, and antimutagenic properties [154]. Uncaria is used in phytotherapy in treating chronic inflammatory diseases, immune deficiencies, in the pres- ence of viral infections, and the prevention and treatment of common cold with fever and cough $[155,156]$.

\section{Conclusions}

There is evidence that some non-pharmacological substances significantly improve post-viral acute cough and reduce common cold-dependent symptoms. This evidence confirms the popular tradition of using natural compounds to relieve cough and the common cold favorably. However, many natural components have not been sufficiently investigated. Further studies should be addressed to respond to this unmet need.

\section{References}

1. Centers for Disease Control and Prevention. Common cold. Availabl from: https://www.cdc.gov/dotw/commoncold/index.html

2. Galway NC, Shields MD. The child with an incessant dry cough. Pediatr Resp Rev 2019;30:58-64.

3. Chang AB, Oppenheimer JJ, Irwin RS. Managing chronic cough as a symptom in children and management algorithms. Chest 2020;158:303-29.

4. Finley CR, Chan DS, Garrison S, et al. What are the most common conditions in primary care? Can Fam Phys 2018;64:832-40.

5. Anderson-James S, Marchant JM, et al. Burden and emergency department management of acute cough in children. J Pediatr Child Health 2018;55:181-7.

6. DeGeorge KC, Ring DJ, Dalrymple SN. Treatment of the common cold. Am Fam Physic 2019;100:281-9.

7. Fokkens W, Lund V, Hopkins C, et al. EPOS2020: European Position Paper on Rhinosinusitis and Nasal Polyps 2020. Rhinology 2020;58:S1-464.

8. Thompson M, Vodicka TA, Blair PS, et al. Duration of symptoms of respiratory tract infections in children: a systematic review. BMJ 2013;347:f7027.

9. De Blasio F, Dicpinigaitis PV, Rubin BK, et al. An observational study on cough in children: Epidemiology, impact on quality of sleep and treatment outcome. Cough 2012;8:1.

10. Goldman RD. Treating cough and cold: Guidance for caregivers of children and youth. Paediatr Child Health 2011;16:564-6.

11. Degeorge KC, Ring DJ, Dalrymple SN. Treatment of the common cold. Am Fam Physician 2019;100:281-9.

12. Morice AH. Over-the-counter cough medicines: new approaches. Pulm Pharmacol Therap 2015;1-3.

13. Smith SM, Schroeder K, Fahey T. Over-the-counter (OTC) medications for acute cough in children and adults in community settings. Cochrane Database Syst Rev 2014;2014: CD001831.

14. Goldman RD. Honey for treatment of cough in children. Can Fam Physician 2014;60:1107-8.

15. Avner Cohen H, Rozen J, Kristal H, et al. Effect of honey on nocturnal cough and sleep quality: a double-blind, randomized, placebo-controlled study. Pediatrics 2012;130:465-71.

16. World Health Organization. Cough and cold remedies for the treatment of acute respiratory infections in young children. Geneva: World Health Organization; 2001. 
17. Cianciosi D, Forbes-Hermandez TY, Afrin S, et al. Phenolic compounds in honey and their associated health benefits: a review. Molecules 2018;23:2322.

18. Shadkam MN, Mozaffari-Khosravi H, Mozayan MR. A comparison of the effect of honey, dextromethorphan, and diphenhydramine on nightly cough and sleep quality in children and their parents. J Altern Complement Med 2010;16:787-93.

19. Cohen HA, Rozen J, Kristal H, et al. Effect of honey on nocturnal cough and sleep quality: a double-blind, randomized, placebo-controlled study. Pediatrics 2012;130:465-71.

20. Murgia V, Manti S, Licari A, et al. Upper respiratory tract infection-associated acute cough and the urge to cough: New insights for clinical practice. Pediatr Allergy Immunol Pulmonol 2020;33:3-13.

21. Malesker MA, Callahan-Lyon $P$, Ireland $B$, et al. Pharmacologic and nonpharmacologic treatment for acute cough associated with the common cold: CHEST Expert Panel Report. Chest 2017;152:1021-37.

22. Oduwole O, Udoh EE, Oyo-Ita A, Meremikwu MM. Honey for acute cough in children. Cochrane Database Syst Rev 2018;2018:CD007094.

23. Cohen HA, Hoshen M, Gur S, et al. Efficacy and tolerability of a polysaccharide-resin-honey vased cough syrup as compared to carbocysteine syrup for children with colds: a randomized, single-blinded, multicenter study. World J Pediatr 2017;13:27-33

24. Canciani M, Murgia V, Caimmi D, et al. Efficacy of Grintuss ${ }^{\circledR}$ pediatric syrup in treating cough in children: a randomized, multicenter, double-blind, placebo-controlled clinical trial. Ital J Pediatr 2014;40:56.

25. Wikström S, Holst E. [Infant botulism - Why honey should be avoided for children up to one year].[Article in Swedish]. Lakartidningen 2017;114:ELMF.

26. Cox N, Hinkle R. Infant botulism. Am Fam Physician 2002;65:1388-92.

27. Cohen HA, Rozen J, Kristal H, Lacks Y. Effect of honey on nocturnal cough and sleep quality: a double-blind, randomized, placebo-controlled study. Pediatrics 2012;130:465-71.

28. Lee VS, Humpreys IM, Purcell PL, Davis GE. Manuka honey sinus irrigation for the treatment of chronic rhinosinusitis: A randomized controlled trial. Int Forum Allergy Rhinol 2017;7:365-72.

29. Pasupuleti VR, Sammugam L, Ramesh N, Gan SH. Honey, propolis, and royal jelly: A comprehensive review of their biological actions and health benefits. Oxid Med Cell Longev 2017;2017:1259510.

30. Soromou LW, Zhang Y, Cui Y, et al. Subinhibitory concentrations of pinocembrin exert anti-staphylococcus aureus activity by reducing $\alpha$-toxin expression. J Appl Microbiol 2013;115:41-9.

31. Bosio K, Avanzini C, D'Avolio A, et al. In vitro activity of propolis against Streptococcus pyogenes. Lett Appl Microbiol 2000;3:174-7

32. Borrelli F, Maffia P, Pinto L, et al. Phytochemical compounds involved in the anti-inflammatory effect of propolis extract. Fitoterapia 2002;73:S53-63.

33. Wu YH, Zhang BY, Qiu LP, et al. Structure properties and mechanisms of action of naturally originated phenolic acids and their derivatives against human viral infections. Curr Med Chem 2017;24:4279-302.

34. Holmiere S, Valentin R, Marechal P, Mouloungui Z. Esters of oligo-(glycerol carbonate-glycerol): New biobased oligomeric surfactants. J Colloid Interface Sci 2017;487:418-25.
35. Eccles R. The powerful placebo in cough studies. Pulm Pharmacol Ther 2002;15:303-8.

36. Shrivastava R, Carrois F, Pisak M, et al. Clinical efficacy of novel filmogen, antimicrobial, cleaning, fluidizing cough treatment. J Clin Trials 2017;7:318.

37. Eccles R, Mallefet P. Soothing properties of glycerol in cough syrups for acute cough due to common cold. Pharmacy (Basel) 2017;5:4.

38. World Health Organization. Cough and cold remedies for the treatment of acute respiratory infections in young children. Geneva: World Health Organization; 2001.

39. Medicines and Healthcare products Regulatory Agency. Risk: benefit of OTC cough and cold medicines in children. 2009. Availabel from: http:/www.mhra.gov.uk/Safetyinformation/S afetywarningsalertsandrecalls/

40. Kamatou GP, Vermaak I, Viljoen AM, Lawrence BM. Menthol: A simple monoterpene with remarkable biological properties. Phytochemistry 2013;96:15-25.

41. Smith AP, Boden C. Effects of chewing menthol gum on the alertness of healthy volunteers and those with an upper respiratory tract illness. Stress Health 2011;29:138-42.

42. Gillissen A, Wittig T, Ehmen M, et al. A multi-centre, randomised, double-blind, placebo-controlled clinical trial on the efficacy and tolerability of GeloMyrtol ${ }^{\circledR}$ forte in acute bronchitis. Drug Res (Stuttg) 2013;63:19-27.

43. Birring SS, Brew J, Kilbourn A, et al. Rococo study: a realworld evaluation of an over-the-counter medicine in acute cough (a multicentre, randomised, controlled study). BMJ Open 2017;7:e014112.

44. Johnson D, Mead R, Kennelty K, Hahn D. Menthol cough drops: cause for concern? J Am Board Fam Med 183-91.

45. Caceres AI, Liu B, Jabba SV, et al. Transient receptor potential cation channel subfamily $M$ member 8 channels mediate the anti-inflammatory effects of eucalyptol. $\mathrm{Br} \mathrm{J}$ Pharmacol 2017; 174:867-79.

46. Yu N, Sun Yt, Su XM, et al. Treatment with eucalyptol mitigates cigarette smoke-induced lung injury through suppressing ICAM-1 gene expression. Biosci Rep 2018;38: BSR20171636.

47. Marchese A, Orhan IE, Daglia M, et al. Antibacterial and antifungal activities of thymol: A brief review of the literature. Food Chemistry 2016;210:402-14.

48. Schonknecht K, Krauss H, Jambor J, Fal AM. Treatment of cough in respiratory tract infections - The effect of combining the natural active compounds with thymol. Wiad Lek 2016;69:791-8.

49. Michie CA, Cooper E. Frankincense and myrrh as remedies in children. J R Soc Med 1991;84:602-5.

50. Frémont L. Biological effects of resveratrol. Life Sci 2000;66:663-73

51. Baldassarre ME, Di Mauro A, Labellarte G, et al. Resveratrol plus carboxymethyl- $\beta$-glucan in infants with common cold: A randomized double-blind trial. Heliyon 2020;6:e 03814.

52. Varricchio AM, Capasso M, della Volpe A, et al. Resveratrol plus carboxymethyl- $\beta$-glucan in children with recurrent respiratory infections: A preliminary and real-life experience. Ital J Pediatr 2014;40:93.

53. Ialenti A, Di Rosa M. Hyaluronic acid modulates acute and chronic inflammation. Agents Actions 1994;43:44-7.

54. Ciprandi G, Gelardi M. [Trattamento delle riniti allergiche e vasomotorie: il ruolo del beclometasone dipropionato e dell'acido ialuronico (ad alto peso molecolare)].[Article in Italina]. Rec Progr Med 2018;109:1-9. 
55. Ciofalo A, Zambetti G, Altissimi G, et al. Pathological and cytological changes of the nasal mucosa in acute rhinosinusitis: the role of hyaluronic acid as supportive therapy. Eur Rev Med Pharmacol Sci 2017;21:4411-8.

56. Varricchio A, Capasso M, Avvisati F, et al. Inhaled hyaluronic acid as ancillary treatment in children with bacterial acute rhinopharyngitis. J Biol Reg 2014;28:537-43.

57. Ciprandi G, Gelardi M. Open and clean: the healthy nose. Acta Biomedica 2019;90:S4-6.

58. Gelardi M, Mezzoli A, Fiorella ML, et al. Nasal irrigation with Lavonase as ancillary treatment of acute rhinosinusitis: a pilot study. J Biol Reg 2009;23:79-84.

59. Shaikh N, Wald ER. Decongestants, antihistamines and nasal irrigation for acute sinusitis in children. Cochrane Database Syst Rev 2010;(12):CD007909.

60. Marchisio P, Picca M, Torretta S, et al. Nasal saline irrigation in preschool children: a survey of attitudes and prescribing habits of primary care pediatricians working in northern Italy. Ital J Pediatr 2014;40:47.

61. King D, Mitchell B, Williams CP, Spurling GKP. saline nasal irrigation for acute upper respiratory tract infections. Cochrane Database Syst Rev 2015;(4):CD006821.

62. Ciprandi G, Cristofolini M, Mira E. Comano thermal water inhalations in the treatment of allergic rhinitis: preliminary results. Eur Annals Allergy Clin Immunol 2016;48:220-3.

63. La Mantia I, Ciprandi G, Varricchio A, et al. Salsobromoiodine thermal water: a nonpharmacological alternative treatment for postnasal drip-related cough in children with upper respiratory tract infections. J Biol Regul Homeost Agents 2018;32:41-7.

64. Cupido GF, Gelardi M, La Mantia I, et al. Broncalt, class II medical device, in patients with acute upper airways disease: a survey in clinical practice. Acta Biomed 2019;90:s24-9.

65. European Medicine Agency. HMPC monographs: Overview of recommendations for the uses of herbal medicinal products in the paediatric population. Last update: April 2018. London: European Medicine Agency.

66. Ahmed W, Azmat R, Khan SM, et al. Pharmacological studies of Adhatoda vasica and Calotropis procera as resource of bioactive compounds for various diseases. Pak J Pharm Sci 2018;31:1975-83.

67. Liu W, Wang Y, He DD, et al. Antitussive, expectorant, and bronchodilating effects of quinazoline alkaloids $( \pm)$-vasicine, deoxyvasicine, and $( \pm)$-vasicinone from aerial parts of Peganum harmala L. Phytomedicine 2015;22:1088-95.

68. Khan I, Ahmad B, Azam S, et al. Pharmacological activities of Justicia adhatoda. Pak J Pharm Sci 2018;31:371-7.

69. Barth A, Hovhannisyan A, Jamalyan K, Narimanyan M. Antitussive effect of a fixed combination of Justicia adhatoda, Echinacea purpurea and Eleutherococcus senticosus extracts in patients with acute upper respiratory tract infection: A comparative, randomized, double-blind, placebo-controlled study. Phytomedicine 2015;22:1195-200.

70. Paul IM, Beiler JS, Vallati JR, et al. Placebo effect in the treatment of acute cough in infants and toddlers: a randomized clinical trial. JAMA Pediatr 2014;168:1107-13.

71. Gao Y, Kuok KI, Jin Y, Wang R. Biomedical applications of aloe vera. Crit Rev Food Sci Nutr 2019;59:S244-56.

72. Bonaterra GA, Bronischewski K, Hunold P, et al. Anti-inflammatory and anti-oxidative effects of phytohustil ${ }^{\circledR}$ and root extract of Althaea officinalis L. on macrophages in vitro. Front Pharmacol. 2020;11:290

73. Mahboubi M. Marsh mallow (Althaea officinalis L.) and its potency in the treatment of cough. Complement Med Res 2020;27:174-83.

74. Hagiwara K, Wright PR, Tabandera NK, et al. Comparative analysis of the antioxidant properties of Icelandic and Hawaiian lichens. Environ Microbiol 2016;18:2319-25.

75. Corrales m, Han JH, Tauscher B. Antimicrobial properties of grape seed extracts and their effectiveness after incorporation into pea starch films. Int J Food Sci Technol 2009;44:425-33.

76. Sangdee K, Sangdee A, Srihanam P. Enzyme inhibition and antimicrobial activities of fractionated wild grape seed extracts. Pak J Biol Sci 2020;23:1066-74.

77. Tejada S, Pinya S, Martorell M, et al. Potential anti-inflammatory effects of hesperidin from the genus citrus. Curr Med Chem 2018;25:4929-45.

78. Dosoky NS, Setzer WN. Biological activities and safety of Citrus spp. essential oils. Int J Mol Sci 2018;19:1966.

79. Jopcik M, Moravcikova J, Matusikova I, et al. Structural and functional characterisation of a class I endochitinase of the carnivorous sundew (Drosera rotundifolia L.). Planta 2017;245:313-27.

80. Michalko J, Renner T, Mészáros P, et al. Molecular characterization and evolution of carnivorous sundew (Drosera rotundifolia L.) class Vbeta-1,3-glucanase. Planta 2017;245:77-91.

81. Zehl M, Braunberger C, Conrad J, et al. Identification and quantification of flavonoids and ellagic acid derivatives in therapeutically important Drosera species by LC-DAD, LCNMR, NMR, and LC-MS. Anal Bioanal Chem 2011;400:2565-76.

82. Egan PA, van der Kooy F. Phytochemistry of the carnivorous sundew genus Drosera (Droseraceae) - future perspectives and ethnopharmacological relevance. Chem Biodivers 2013;10:1774-90.

83. Voß HW, Michalsen A, Brünjes R. Efficacy and tolerability of a complex homeopathic drug in children suffering from dry cough-A double-blind, placebo-controlled, clinical trial. Drug Res (Stuttg) 2018;68:444-9.

84. Weber W, Taylor JA, Vander Stoep A, et al. Echinacea purpurea for prevention of upper respiratory tract infections in children. J Altern Complement Med 2005;11:1021-6.

85. Karsch-Völk M, Barrett B, Kiefer D, et al. Echinacea for preventing and treating the common cold. Cochrane Database Syst Rev 2014;(2):CD000530.

86. Wagner L, Cramer H, Klose P, et al. Herbal medicine for cough: a systematic review and meta-analysis. Forsch Komplem 2015;22:359-68.

87. Shah SA, Sander S, White CM, et al. Evaluation of echinacea for the prevention and treatment of the common cold: a metaanalysis. Lancet Infect Dis 2007;7:473-80.

88. Paul IM, Beiler JS, King TS, et al. Vapor rub, petrolatum, and no treatment for children with nocturnal cough and cold symptoms. Pediatrics 2010;126:1092-9.

89. Pastorino G, Cornara L, Soares S, et al. Liquorice (Glycyrrhiza glabra): A phytochemical and pharmacological review. Phytother Res 2018;32:2323-39.

90. Ciprandi G, Bellussi LM, Passali GC, et al. HMGB1 in nasal inflammatory diseases: a reappraisal 30 years after its discovery. Expert Rev Clin Immunol 2020;16:457-463.

91. Tanaka H, Hasegawa T, Matsushita M, et al. Quantitative evaluation of ocular anti-inflammatory drugs based on measurements of corneal temperature in rabbits: dexamethasone and glycyrrhizin. Ophthalmic Res 1987;19:213-20.

92. Akamatsu H, Komura J, Asada Y, Niwa Y. Mechanism of antiinflammatory action of glycyrrhizin: effect on neutrophil 
functions including reactive oxygen species generation. Planta Med 1991;57:119-21.

93. Fiore C, Eisenhut M, Krausse R, et al. Antiviral effects of Glycyrrhiza species. Phytother Res 2008 22:141-8.

94. Kamei J, Nakamura R, Ichiki H, Kubo M. Antitussive principles of Glycyrrhizae radix, a main component of the Kampo preparations Bakumondo-to (Mai-men-dong-tang). Eur J Pharmacol 2003;469:159-63.

95. Yanagawa Y, Ogura M, Fujimoto E, Shono S, Okuda E. Effects and cost of glycyrrhizin in the treatment of upper respiratory tract infections in members of the Japanese maritime self-defense force: Preliminary report of a prospective, randomized, double-blind, controlled, parallel-group, alternateday treatment assignment clinical trial. Curr Ther Res Clin Exp 2004;65:26-33.

96. Reta GF, Chiaramello AI, García C, et al. Derivatives of grindelic acid: from a non-active natural diterpene to synthetic antitumor derivatives. Eur J Med Chem 2013;67:28-38.

97. Theisen LL, Erdelmeier AJ, Spoden GA, et al. Tannins from Hamamelis virginiana bark extract: Characterization and improvement of the antiviral efficacy against influenza A virus and human papillomavirus. PLoS One 2014;9:e88062.

98. Alanija M, Shalashvili K, Sagareishvili T, et al. Study of antioxidant activity of phenolic compounds from some species of Georgian flora. Georgian Med News 2013;222:69-72

99. Beikert FC, Schonfeld BS, Frank U, Augustin M. Antiinflammatory potential of seven plant extracts in the ultraviolet erythema test. A randomized, placebo-controlled study. Hautarzt 2013;64:40-6.

100. Olszanecka-Glinianowicz M, Doniec Z, Schönknecht K, Almgren-Rachtan A. The herbal medicine containing of ivy leaf dry extract in the treatment of productive cough in children. Wiad Lek 2020;73:668-73.

101. Kruttschnitt E, Wegener T, Zahner C, Henzen-Bücking S. Assessment of the efficacy and safety of ivy leaf (Hedera helix) cough syrup compared with acetylcysteine in adults and children with acute bronchitis. Evid Based Complement Alternat Med 2020;2020:1910656.

102. Khan MF, Akram M, Akhter N, et al. The evaluation of efficacy and safety of cough (EMA) granules used for upper respiratory disorders. Pak J Pharm Sci 2018;31:S2617-22.

103. Büechi S, Vögelin R, von Eiff MM, et al. Open trial to assess aspects of safety and efficacy of a combined herbal cough syrup with ivy and thyme. Forsch Komplementarmed Klass Naturheilkd 2005;12:328-32.

104. Fraternale D, Flamini G, Ascrizzi R. In vitro anticollagenase and antielastase activities of essential oil of Helichrysum italicum subsp. Italicum (Roth) G. Don. J Med Food 2019;22:1041-6.

105. Antunes Viegas D, Palmeira-de-Oliveira A, Salgueiro L, et al. Helichrysum italicum: from traditional use to scientific data. Ethnopharmacol 2014;151:54-65.

106. Viegas DA, Plameira-de-Oliveira A, Salgueiro L, et al. Helichrysum italicum: From traditional use to scientific data. J Ethnopharmacol 2014;151:54-65.

107. Nowakowska A, Caputa M, Rogalska J. Defence against oxidative stress in two species of land snails (Helix pomatia and Helix aspersa) subjected to estivation. J Exp Zool A Ecol Genet Physiol 2011;315:593-601.

108. Greistorfer S, Klepal W, Cyran N, et al. Snail mucus - glandular origin and composition in Helix pomatia. Zoology (Jena) 2017;122:126-38.

109. Cutillo F, D'Abrosca B, Dellagreca M, et al. Terpenoids and phenol derivatives from Malva silvestris. Phytochemistry 2006; 67:481-5.

110. Popoola OK, Elbagory AM, Ameer F, Hussein AA. Marrubiin. Molecules 2013;18:9049-60.

111. Rezgui M, Majdoub N, Mabrouk B. Antioxidant and antifungal activities of marrubiin, extracts and essential oil from Marrubium vulgare L. against pathogenic dermatophyte strains. J Mycol Med 2020;30:100927.

112. Amri B, Martino E, Vitulo F, et al. Marrubium vulgare L. leave extract: Phytochemical composition, antioxidant and wound healing properties. Molecules 2017;22:1851.

113. McKay DL, Blumberg JB. A review of the bioactivity and potential health benefits of peppermint tea (Mentha piperita). Phytother Res 2006;20:619-33.

114. Ben-Arye E, Dudai N, Eini A, et al. Treatment of upper respiratory tract infections in primary care: a randomized study using aromatic herbs. Evid Based Complement Alternat Med 2011;2011:690346.

115. Carlassare M. [Proposal for the Pharmacopeia: tolu balsam fluid extract].[Article in Italian]. Boll Chim Farm 1980;119:731-7.

116. Oh JH, Ha IJ, Lee MY, et al. Identification and metabolite profiling of alkaloids in aerial parts of Papaverrhoeas by liquid chromatography coupled with quadrupole time-of-flight tandem mass spectrometry. J Sep Sci 2018;41:2517-27.

117. Qidwai W, Alim SR, Dhanani RH, et al. Use of folk remedies among patients in Karachi Pakistan. J Ayub Med Coll Abbottabad 2003;15:31-3.

118. Martin D, Konrad M, Adarkwah CC, Kostev K. Reduced antibiotic use after initial treatment of acute respiratory infections with phytopharmaceuticals- A retrospective cohort study. Postgrad Med 2020;20:1-7

119. Min BG, Park SM, Choi YW, et al. Effects of Pelargonium sidoides and Coptis Rhizoma 2:1 mixed formula (PS+CR) on ovalbumin-induced asthma in mice. Evid Based Complement Alternat Med 2020;2020:9135637.

120. Wagner L, Cramer H, Klose P, et al. Herbal medicine for cough: a systematic review and meta-analysis. Forsch Komplem 2015;22:359-68.

121. Basholli-Salihu M, Schuster R, Hajdari A, et al. Phytochemical composition, anti-inflammatory activity and cytotoxic effects of essential oils from three Pinus spp. Pharm Biol 2017;55:1553-60.

122. Bottoni M, Milani F, Colombo L, et al. Using medicinal plants in Valmalenco (Italian alps): from tradition to scientific approaches. Molecules 2020;25:4144.

123. De Cassia Israel Cardoso F, Peruzzo Apolinario P, da Silva Cunha Breder J, et al. A protocol for systematic review of Plantago major L. effectiveness in accelerating wound-healing in animal models. Syst Rev 2019;8:337.

124. Zeng X, Guo F, Ouyang D. A review of the pharmacology and toxicology of aucubin. Fitoterapia 2020;140:104443.

125. Possebon L, de Souza Lima Lebron I, Furlan da Silva L, et al. Anti-inflammatory actions of herbal medicines in a model of chronic obstructive pulmonary disease induced by cigarette smoke. Biomed Pharmacother 2018;99:591-7.

126. Najafian Y, Hamedi SS, Farshchi MK, et al. Plantago major in traditional Persian medicine and modern phytotherapy: a narrative review. Electron Physician 2018;10:6390-9.

127. Arruda-Silva F, Nascimento MV, Luz AB, et al. Polygala molluginifolia A. St.-Hil. and Moq. prevent inflammation in the mouse pleurisy model by inhibiting NF-kappaB activation. Int Immunopharmacol 2014;19:334-41. 
128. Zhao X, Cui Y, Wu P, et al. Polygalae radix: A review of its traditional uses, phytochemistry, pharmacology, toxicology, and pharmacokinetics. Fitoterapia 2020;147:104759.

129. Kis B, Avram S, Pavel IZ, et al. Recent advances regarding the phytochemical and therapeutic uses of Populus nigra L. buds. Plants (Basel) 2020;9:e1464.

130. Pobłocka-Olech L, Inkielewicz-Stepniak I, KrauzeBaranowska M. Anti-inflammatory and antioxidative effects of the buds from different species of Populus in human gingival fibroblast cells: Role of bioflavanones. Phytomedicine 2019;56:1-9.

131. Cortez RE, Gonzalez de Mejia E. blackcurrants (ribes nigrum): a review on chemistry, processing, and health benefits. J Food Sci 2019;84:2387-401.

132. Nakaishi H, Matsumoto H, Tominaga S, Hirayama M. Effects of black current anthocyanoside intake on dark adaptation and VDT work-induced transient refractive alteration in healthy humans. Altern Med Rev 2000;5:553-62.

133. Ferlemi AV, Lamari FN. Berry leaves: An alternative source of bioactive natural products of nutritional and medicinal value. Antioxidants (Basel) 2016;5:17.

134. Chrubasik C, Roufogalis BD, Müller-Ladner U, Chrubasik S. A systematic review on the Rosa canina effect and efficacy profiles. Phytother Res 2008;22:725-33.

135. Ayati Z, Amiri MS, Ramezani M, et al. Phytochemistry, traditional uses and pharmacological profile of rose hip: A review. Curr Pharm Des 2018;24:4101-24.

136. Ghorbani A, Esmaeilizadeh M. Pharmacological properties of Salvia officinalis and its components. J Tradit Complement Med 2017;7:433-40.

137. Jakovljević M, Jokić S, Molnar M, et al bioactive profile of various Salvia officinalis L. preparations. Plants (Basel) 2019;8:55.

138. Rakover Y, Ben-Arye E, Goldstein LH. [The treatment of respiratory ailments with essential oils of some aromatic medicinal plants].[Article in Hebrew]. Harefuah 2008;147:783-8, 838.

139. Młynarczyk K, Walkowiak-Tomczak D, Łysiak GP. Bioactive properties of Sambucus nigra L. as a functional ingredient for food and pharmaceutical industry. J Funct Foods 2018;40:377-90.

140. Porter RS, Bode RF. A review of the antiviral properties of black elder (Sambucus nigra L.) products. Phytother Res 2017;31:533-54.

141. Vlachojannis JE, Cameron M, Chrubasik S. A systematic review on the sambuci fructus effect and efficacy profiles. Phytother Res 2010;24:1-8.

142. Zakay-Rones Z, Thom E, Wollan T, Wadstein J. Randomized study of the efficacy and safety of oral elderberry extract in the treatment of influenza A and B virus infections. J Int Med Res 2004;32:132-40.

143. Tiralongo E, Wee SS, Lea RA. Elderberry supplementation reduces cold duration and symptoms in air-travellers: A randomized, double-blind placebo-controlled clinical trial. Nutrients 2016;8:182.

144. Harnett J, Oakes K, Carè J, et al. The effects of Sambucus nigra berry on acute respiratory viral infections: A rapid review of clinical studies. Adv Integr Med 2020;7:240-6.

145. Hawkins J, Baker C, Cherry L, Dunne E. Black elderberry (Sambucus nigra) supplementation effectively treats upper respiratory symptoms: A meta-analysis of randomized, controlled clinical trials. Complement Ther Med 2019;42:361-5.

146. Pasdaran A, Pasdaran A, Sheikhi D. Volatile oils: Potential agents for the treatment of respiratory infections. In: K Jon, Rai M, editors. The microbiology of respiratory system infections. Amsterdam: Elsevier; 2016. p. 237-61.

147. Fani M, Kohanteb J. In vitro antimicrobial activity of Thymus vulgaris essential oil against major oral pathogens. J Evid Based Complementary Altern Med 2017;22:660-6.

148. Kemmerich B, Eberhardt R, Stammer H. Efficacy and tolerability of a fluid extract combination of thyme herb and ivy leaves and matched placebo in adults suffering from acute bronchitis with productive cough. A prospective, doubleblind, placebo-controlled clinical trial. Arzneimittelforschung 2006;56:652-60-

149. Kemmerich B. Evaluation of efficacy and tolerability of a fixed combination of dry extracts of thyme herb and primrose root in adults suffering from acute bronchitis with productive cough. A prospective, double-blind, placebo-controlled multicentre clinical trial. Arzneimittelforschung 2007;57:607-15

150. Büechi S, Vögelin R, von Eiff MM, et al. Open trial to assess aspects of safety and efficacy of a combined herbal cough syrup with ivy and thyme. Forsch Komplementarmed Klass Naturheilkd 2005;12:328-32.

151. Jabeur I, Martins N, Barros L, et al. Contribution of the phenolic composition to the antioxidant, anti-inflammatory and antitumor potential of Equisetum giganteum L. and Tilia platyphyllos scop. Food Funct 2017;8:975-98.

152. Calderón-Montaño JM, Burgos-Morón E, Pérez-Guerrero C, López-Lázaro M. A review on the dietary flavonoid kaempferol. Mini Rev Med Chem 2011;11:298-344.

153. Navarro M, Arnaez E, Moreira I, et al. Polyphenolic composition and antioxidant activity of Uncaria tomentosa commercial bark products. Antioxidants (Basel) 2019;8:339.

154. Della Valle V. Uncaria tomentosa. G Ital Dermatol Venereol 2017;152:651-7.

155. Almeida IV, Soares LC, Lucio FT, et al. Chemotherapeutical effects of the herbal medicine Uncaria tomentosa (Willd.) DC. Genet Mol Res 2017;16:gmr16039782.

156. Carvalho MV, Penido C, Siani AC, et al. Investigations on the anti-inflammatory and anti-allergic activities of the leaves of Uncaria guianensis (Aublet) J.F. Gmelin. Inflammopharmacology 2006;14:48-56. 